\title{
ANALISIS KADAR NITRIT (NO2) PADA AIR SUMUR BOR DI DAERAH PERSAWAHAN DESA TO'E KECAMATAN TIROANG KABUPATEN PINRANG
}

\author{
Nuradi $^{1}$, Tri Wahyuni Sam ${ }^{2}$ \\ 1,2 Jurusan Analis Kesehatan Poltekkes Makassar
}

Koresponden : nuradi.poltekkes.mks@gmail.com

\begin{abstract}
ABSTRAK
Penelitian ini dilatarbelakangi kemungkinan adanya kadar nitrit $\left(\mathrm{NO}_{2}\right)$ pada air sumur bor yang diakibatkan karena penggunaan pupuk yang berlebihan dan dapat mencemari air tanah. Tujuan penelitian ini yaitu untuk mengetahui kadar nitrit yang terkandung dalam air sumur bor, yang menggunakan Spektrofotometer UV-Vis dengan panjang gelombang $523 \mathrm{~nm}$ dan dilakukan dengan analisis kuantitatif. Sampel yang diperiksa sebanyak 5 dan pengambilan sampel dilakukan secara acak (random). Dari hasil analisis kuantitatif maka diperoleh kandungan rata-rata kadar nitrit $\left(\mathrm{NO}_{2}\right)$ dalam masing-masing sampel yaitu 0,$0010 ; 0,0016 ; 0,0077 ; 0,0042$ dan 0,0102 ppm. Dari hasil yang diperoleh tersebut disimpulkan bahwa semua sampel yang telah diperiksa memenuhi syarat yang telah ditetapkan dalam Peraturan Menkes RI No.907/MENKES/SK/VII/2002, yakni kadar nitrit $\left(\mathrm{NO}_{2}\right)$ dalam air tidak lebih dari 3 ppm sehingga tidak membahayakan kesehatan serta dapat dikonsumsi oleh masyarakat. Disarankan kepada peneliti selanjutnya agar meneliti unsur-unsur kimia lain dalam air sumur bor.
\end{abstract}

Kata kunci : Nitrit, Air Sumur Bor

\section{PENDAHULUAN}

Air merupakan senyawa kimia yang sangat penting bagi kehidupan umat manusia dan makhluk hidup lainnya dan fungsinya bagi kehidupan tersebut tidak akan dapat digantikan oleh senyawa lainnya. Hampir semua kegiatan yang dilakukan manusia membutuhkan air termasuk untuk memenuhi kebutuhan sehari-hari (Achmad R, 2004).

Sumber daya air harus dilindungi agar tetap dapat dimanfaatkan dengan baik oleh manusia serta makhluk hidup yang lain. Pemanfaatan air untuk berbagai kepentingan harus dilakukan secara bijaksana, dengan memperhitungkan kepentingan generasi sekarang maupun generasi mendatang. Aspek penghematan dan pelestarian sumber daya air harus ditanamkan pada segenap pengguna air.

Masalah yang dihadapi sumber daya air saat ini meliputi kuantitas air yang sudah tidak mampu memenuhi kebutuhan yang terus meningkat dan kualitas air untuk keperluan domestik (rumah tangga) yang semakin menurun. Kondisi ini dapat 
menimbulkan gangguan, kerusakan, dan bahaya bagi semua makhluk hidup sehingga diperlukan pengelolaan dan perlindungan sumber air secara seksama (Effendi H, 2003).

Salah satu penyebab menurunnya kualitas air adalah masalah pencemaran lingkungan termasuk pencemaran air tanah. Pencemaran air tanah dipengaruhi oleh beberapa faktor yaitu kondisi topografi, karakteristik materi yang ada dipermukaan air tanah, dan karakteristik materi dimana air tanah berada. Topografi yang datar dan material yang porous memudahkan air tanah tercemar dari pada topografi yang terjal material kedap. (Widodo P, 2008).

Desa To'e merupakan daerah yang memiliki tekstur tanah pasir sehingga di kenal sebagai daerah persawahan yang memiliki lahan dengan tingkat kesuburan yang rendah sehingga memerlukan pupuk urea untuk meningkatkan kesuburan tanahnya. Pemberian pupuk urea yang berlebihan dapat mencemari air tanah yang digunakan oleh masyarakat desa To'e sebagai air minum. Pencemaran yang diakibatkan oleh kegiatan pertanian tersebut dapat meningkatkan kadar nitrit dalam air tanah. Nitrat dan nitrit dapat terbentuk karena tiga proses yaitu badai listrik, organisme pengikat nitrogen, dan bakteri yang menggunakan amoniak. Ketiganya tidak dibantu oleh manusia, tetapi jika manusia menggunakan pupuk serta membuang limbah rumah tangga (domestik) yang banyak mengandung amoniak di atas tanah maka proses ketiga akan meningkat karena pupuk dan limbah rumah tangga banyak mengandung amoniak. Kemungkinan lain penyebab konsentrasi nitrit meningkat dalam air tanah adalah pembusukan sisa tanaman dan hewan, pembuangan industry dan kotoran hewan (Sastrawijaya T, 2000).

Kandungan nitrit yang berlebihan dalam air minum menurut Permenkes RI No. 907/MENKES/SK/VII/2002 yaitu lebih dari 3 ppm dapat mengganggu system peredaran darah dimana hemoglobin berikatan dengan nitrit dan menimbulkan keracunan dengan gejala kulit berwarna biru (Sastrawijaya T, 2000).

Berdasarkan latar belakang tersebut maka penulis telah melakukan penelitian analisis kadar Nitrit $\left(\mathrm{NO}_{2}\right)$ pada air sumur bor di Daerah Persawahan Desa To'e Kecamatan Tiroang Kabupaten Pinrang

\section{METODE}

Jenis penelitian adalah observasi laboratorik bersifat deskriptif analitik dengan teknik analisa kuantitatif untuk menentukan kadar nitrit pada air sumur bor di daerah persawahan desa To'e Kecamatan Tiroang Kabupaten Pinrang.

Penelitian ini dilaksanakan di Balai Besar Laboratorium Kesehatan Makassar pada bulan Juni 2016. Sampel yang digunakan yaitu air sumur bor diambil secara random sampling sebanyak 5 sampel di daerah persawahan desa To'e Kecamatan Tiroang Kabupaten Pinrang.

Alat penelitian yang digunakan adalah: Spektrofotometer UV-Vis, labu ukur, gelas kimia, corong, sendok tanduk, neraca analitik, labu erlenmeyer, kertas saring, pipet tetes, 
pipet volume $5 \mathrm{ml}, 10 \mathrm{ml}, 10 \mathrm{ml}$, biuret dan penangas air. Sampel air sumur bor di daerah persawahan desa To'e Kecamatan Tiroang Kabupaten Pinrang, Aquades bebas nitrit, Reagen sulfanilamide, Larutan N (1-naftil) etilen diamin dihidrocholorida, Larutan $\mathrm{NaOH} 0,1 \mathrm{~N}, \mathrm{HCl} 0,1 \mathrm{~N}$, Larutan standar Nitrit $\left(\mathrm{NO}_{2}\right)$.

Prosedur Kerja

1. Cara kerja :

\section{A. Pembuatan Larutan Standar}

1) Pembuatan larutan standar yaitu ditimbang $150 \mathrm{mg}$ baku natrium nitrit dimasukkan ke dalam labu ukur $100 \mathrm{ml}$, ditambahkan aquades sampai tanda. (larutan baku induk $1000 \mathrm{ppm})$.

2) Larutan standar 1000 ppm dipipet $10 \mathrm{ml}$ ke dalam labu ukur $100 \mathrm{ml}$ kemudian ditambahkan aquades sampai pada garis tanda. (larutan baku 100 ppm)

3) Larutan standar $100 \mathrm{ppm}$ pipet $10 \mathrm{ml}$ ke dalam labu ukur $100 \mathrm{ml}$, kemudian ditambahkan aquades sampai garis tanda. (larutan baku intermediet)

4) Larutan baku seri dibuat dengan memipet larutan baku intermediet $10 \mathrm{ppm}$ masingmasing $1 \mathrm{ml}, 2 \mathrm{ml}, 3 \mathrm{ml}, 4 \mathrm{ml}$, $5 \mathrm{ml}$, ke dalam labu ukur 50 ml, kemudian ditambahkan aquades sampai garis tanda dengan konsentrasi masingmasing 0,2 ppm; 0,4 ppm; 0,6 ppm; 0,8 ppm; 1.0 ppm.

5) $10 \mathrm{ml}$ larutan sulfanilamide dan $6 \mathrm{ml}$ larutan asam klorida
Ditambahkan kedalam larutan seri. Larutan dikocok dan dibiarkan dalam ruangan gelap selama 5 menit.

6) Ditambahkan $2 \mathrm{ml}$ larutan naptiletilen diamin, larutan dikocok dan didiamkan dalam ruangan gelap selama 3 menit

7) Absorbansi diukur dengan konsentrasi nitrit $\left(\mathrm{NO}_{2}\right)$

B. Penetapan Sampel

1) $25 \mathrm{ml}$ air dipipet kedalam labu Erlenmeyer, kemudian $\mathrm{pH}$ air diperiksa. $\mathrm{pH}$ dibawah 7 ditambahkan $\mathrm{NaOH} 0$,I N hingga mencapai $\mathrm{pH} 7 \mathrm{pH}$ netral).

2) Ditambahkan $0,5 \mathrm{ml}$ larutan sulfanilamide, kemudian didiamkan 2 menit

3) Ditambahkan 0,5 ml larutan naftil etilen, larutan di homogenkan.

4) Didiamkan 10 menit,warna yang terjadi diukur dengan spektrofotometer UV-Vis pada panjang gelombang 510 $\mathrm{nm}$.

5) Konsentrasi nitrit dibaca berdasarkan absorbansi larutan sampel pada kurva standar.

Data yang diperoleh dari hasil pengukuran serapan larutan baku dengan panjang gelombang $523 \mathrm{~nm}$ ditabulasi dalam bentuk grafik antara serapan dan konsentrasi, dimana nilainilai serapan pada sumbu $Y$ dan konsentarsi pada sumbu $\mathrm{X}$, kemudian ditarik garis antara titik.

Persamaan Regresi : $\mathrm{Y}=\mathrm{a}+\mathrm{bX}$ $\mathrm{Y}=$ Serapan 
$\mathrm{X}=$ Konsentrasi

$\mathrm{a}=$ konstanta

$\mathrm{b}=$ kemiringan / slope

Nilai a dan $b$ dapat dihitung dengan menggunakan persamaan :

$$
a=\frac{\Sigma y-b(\Sigma x)}{n} \quad b=\frac{n(\Sigma x y)-(\Sigma x)(\Sigma y)}{n\left(\Sigma x^{2}\right)-(\Sigma x)^{2}}
$$

\section{HASIL}

Berdasarkan penelitian yang dilakukan di Balai Besar Laboratorium Kesehatan Makassar pada tanggal 05 Juli 2010, maka diperoleh hasil penelitian terhadap air sumur bor di daerah persawahan desa To'e kecamatan Tiroang Kabupaten Pinrang ditunjukkan pada tabel berikut:

Tabel 1. Hasil Pengukuran Serapan larutan Baku Nitrit $\left(\mathrm{NO}_{2}\right)$ Dengan Sprektrofotometer UV-Vis Pada Panjang Gelombang $523 \mathrm{~nm}$

\begin{tabular}{ccc}
\hline NO. & $\begin{array}{c}\text { Konsentrasi } \\
(\mathbf{p p m})\end{array}$ & Serapan (A) \\
\hline 1 & 0,0000 & 0,048 \\
2 & 0,2000 & 0,210 \\
3 & 0,4000 & 0,383 \\
4 & 0,6000 & 0,529 \\
5 & 0,8000 & 0,691 \\
6 & 1,0000 & 0,875
\end{tabular}

Sumber : Data primer Juli 2010

Tabel 2. Hasil analisis kadar nitrit pada sampel air sumur bor dengan spektrofotometer uv-vis pada panjang gelombang $523 \mathrm{~nm}$.

\begin{tabular}{cccc}
\hline $\begin{array}{c}\text { Sampel Air } \\
\text { Sumur Bor }\end{array}$ & $\begin{array}{c}\text { Serapan } \\
(\mathbf{A})\end{array}$ & $\begin{array}{c}\text { Konsentrasi } \\
(\mathbf{p p m})\end{array}$ & $\begin{array}{c}\text { Konsentrasi } \\
\text { Rata-rata (ppm) }\end{array}$ \\
\hline 1 & 0,048 & 0,0010 & 0,0010 \\
& 0,048 & 0,0010 & \\
2 & 0,049 & 0,0022 & 0,0016 \\
& 0,048 & 0,0010 & \\
3 & 0,053 & 0,0071 & 0,0077 \\
& 0,054 & 0,0083 & \\
4 & 0,051 & 0,0047 & 0,0041 \\
& 0,050 & 0,0034 & \\
5 & 0,056 & 0,0108 & 0,0102 \\
& 0,055 & 0,0096 & \\
\hline
\end{tabular}




\section{PEMBAHASAN}

Analisis kadar nitrit pada air sumur bor di daerah persawahan desa To'e Kecamatan Tiroang Kabupaten Pinrang yang di manfaatkan oleh masyarakat untuk memenuhi kebutuhan sehari-hari seperti memasak, minum, mandi, mencuci dan lain sebagainya dilakukan penelitian secara kuantitatif terhadap 5 sampel yang diambil secara acak (random). Sampel tersebut direaksikan dengan larutan sulfanilamide yang diazotasikan dengan larutan N-(1naftil) etilendiamina dalam suasana asam membentuk warna ungu kemerahan yang dapat diukur serapannya secara spektrofotometri pada panjang gelombang $523 \mathrm{~nm}$. Penambahan reagen secara berurutan dan inkubasi yang tepat pada suhu yang diketahui dapat menghasilkan reaksi yang optimal dan warna yang stabil.

Hasil analisis kandungan nitrit pada sampel air sumur bor yang terlihat dalam tabel diatas menunjukkan bahwa semua air sumur bor yang diperiksa mengandung ion nitrit $\left(\mathrm{NO}_{2}\right)$ dengan kadar yang bervariasi diantaranya sampel 1)

0,0010 ; 2) 0,0016 ; 3) 0,0077 ; 4)

0,0041; 5) 0,0102 ppm.

Menurut siklusnya, bakteri akan mengubah nitrogen menjadi nitrat yang kemudian digunakan oleh tumbuh-tumbuhan. Hewan yang memakan tumbuh-tumbuhan kemudian menggunakan nitrat untuk menghasilkan protein di dalam tubuh. Setelah itu, nitrat akan dikeluarkan kembali ke lingkungan dari kotoran hewan tersebut. Mikroba pengurai kemudian mengubah nitrat yang terdapat dalam bentuk amoniak menjadi nitrit. Setelah itu bakteri di lingkungan akan mengubah nitrit menjadi nitrogen kembali. Dengan adanya siklus tersebut maka air didalam tanah tidak dicemari oleh nitrit yang bersifat toksik bagi tubuh.

Berdasarkan hasil analisis kadar nitrit dalam sampel air sumur bor tersebut dinyatakan memenuhi syarat standar air bersih yang ditetapkan dalam Peraturan Menteri Kesehatan RI No.907/MENKES/ SK/VII/2002 yaitu kurang dari 3 ppm sehingga tidak membahayakan kesehatan dan dapat dikonsumsi oleh masyarakat.

\section{KESIMPULAN}

Berdasarkan hasil penelitian analisis kadar nitrit pada air sumur bor di daerah persawahan desa To'e Kecamatan Tiroang Kabupaten Pinrang secara kuantitatif dengan menggunakan Spektrofotometer UVVis dapat disimpulkan yaitu semua sampel air sumur bor yang diperiksa mengandung nitrit $\left(\mathrm{NO}_{2}\right)$ dengan kadar antara 0,0010 ppm sampai 0,0102 ppm, sehingga dinyatakan memenuhi syarat standar air bersih yang diperbolehkan dalam Peraturan Menkes RI No.907/ MENKES/SK/VII/2002, yakni kadar nitrit $\left(\mathrm{NO}_{2}\right)$ dalam air tidak lebih dari 3 ppm.

\section{SARAN}

Bagi petani agar pemberian pupuk terhadap tanaman yang dilakukan selama ini dapat dikurangi dan dilakukan secara teratur untuk menghindari pencemaran air tanah 
Jurnal Media Analis Kesehatan, Vol. 10, No.1, Juni 2019

http://journal.poltekkes-mks.ac.id/ojs2/index.php/mediaanalis

e-ISSN : 2621-9557

p-ISSN : 2087-1333

oleh ion nitrit dan ion nitrat yang dapat mengganggu derajat kesehatan.

\section{DAFTAR PUSTAKA}

Achmad R, 2004. Kimia Lingkungan, Yogyakarta : Andi Yogyakarta

Effendi H, 2003. Telaah Kualitas Air, Yogyakarta : Kanisius

Sastrawijaya T, 2000. Pencemaran Lingkungan, Jakarta : Rineka Cipta

Widodo P, 2010. Pencemaran Tanah Oleh Penggunaan Pupuk Nitrogen. $\quad$ www.Google.com. Diakses pada tanggal $15 \mathrm{Mei}$ 2010, Makassar 